\title{
Effects of Vermicompost and NPK Fertilizer to Growth and Yield of Mustard Plant (Brassica Juncea L) on Tropical Peatlands
}

\author{
Bambang S.Lautt, Yustinus Sulistiyanto, Prasetia Panca Sakti, Emmy Uthanya Antang \\ Faculty of Agriculture, Palangka Raya University \\ Email: blautt63@gmail.com
}

\begin{abstract}
This research aims to determine the effect of the application Vermicompost Organic Fertilizer and NPK inorganic fertilizer in different doses to see mustard plants' growth and the yield on the media of inland peat soil. The study was a completely randomized design factorial Completely Randomized Design, consisting of 2 treatment factors and three replications. The first factor is the dose of Vermicompost organic fertilizer (D), which consisting of 3 levels i,e D0 : control ; D1: $100 \mathrm{~g} /$ polybag; D2 : $200 \mathrm{~g} /$ polybag and the second factor is the dose NPK Fertilizer which consisting of 2 levels M0: control; M1: $1 \mathrm{~g} /$ polibag. This research has been conducted on the experimental field department of agriculture cultivation, Faculty of Agriculture, Palangka Raya University, Palangka Raya City, Central Kalimantan from October until December 2017. The results showed that the interaction of Vermicompost organic fertilizer and NPK fertilizer did not give an effect for plant growth parameters. Doses Vermicompost $100 \mathrm{~g} / \mathrm{polybag}$ and NPK $1 \mathrm{~g}$ / polybag gave the highest results to growth and yield of mustard plants; based on the results of the analysis, the treatment of $1 \mathrm{~g} \mathrm{NPK}$ / polybag had a very significant effect on the observed parameters such as plant height, number of leaf, root weight, and total plant weight.
\end{abstract}

Keyword: Vermicompost, organic Fertilizer, NPK inorganic fertilizer, green mustard

\section{Introduction}

Green mustard (Brassica juncea L.) is a type of vegetable with a sub-tropical climate that is very popular with the community in Indonesia. In addition, Green mustard is also able to adapt well to tropical climates. Mustard plants include shortlived annual crops about 30-45 days after planting and can also be planted in the lowlands to the highlands (Puspadi, 1996). The benefits of green mustard are very good in curing headaches, improving kidney function, and helping facilitate digestion. In peatland of Central Kalimantan (Indonesian part of Borneo) alone, the productivity of green mustard in 2014 was 1,623 tons / Ha. However, if compared with the national productivity is still lower (DJH, 2015). The main obstacle faced in cultivating Green mustard in Central Kalimantan in general is agricultural land which is mostly dominated by marginal soils, especially inland peat soils. Inland peatland in the municipality of Palangka Raya City covering an area of $\pm 152,414$ hectares (Department of Food Crops, 2009). According to Radjagukguk (1997) the use of inland peatland for agriculture has several constraints, including the availability of $\mathrm{N}$ for plants is generally low, the ratio of $\mathrm{C} / \mathrm{N}$ content of peat soil is relatively high, the Cation Exchange Capacity (CEC) is high, Base Saturation (BS) is low and reacts acidly (low $\mathrm{pH}$ ). This condition causes the availability of nutrients for plants to be relatively small. According to Rukmana (2002), one of the efforts to increase the yield of this mustard plant is through fertilization. Fertilization aims to improve soil fertility so that plants can grow faster, fertile and healthier. Fertilization can add nutrients not available in the soil in sufficient quantities such as nitrogen, phosphorus and potassium.

Vermicompost is an organic fertilizer that has advantages over other organic fertilizers (Lun, 2005). The vermicompost contains macro and micronutrients, which are useful for plant growth. Examples of vermicompost nutrient content using Eisenia foetida earthworms are $0.63 \%$ nitrogen, $0.35 \%$ phosphorus, $0.20 \%$ potassium, $0.23 \%$ calcium, $0.26 \%$ magnesium, $0.07 \%$ sodium, 17.58 copper $\%$, zinc $0.007 \%$, manganese $0.003 \%$, iron $0.79 \%$, boron $0.21 \%, 41.23 \%$ water storage capacity (Mulat, 2003). Plants will more effectively utilize organic fertilizers combined with inorganic fertilizers. One of the inorganic fertilizers that can be used is NPK compound fertilizer. NPK compound fertilizer is an inorganic fertilizer that is 
often used because it contains three elements that plants need to grow. These elements are nitrogen, phosphorus, and potassium (Sarief, 1986). The interaction of vermicompost fertilizer and NPK fertilizer has the potential to have a positive effect where the application of vermicompost fertilizer as an organic material can improve soil fertility physically, such as improving soil structure, porosity, permeability, increasing water retention capacity so that the ability of the roots to absorb nutrients in the soil will be better. Thus, NPK fertilizer will be more efficiently absorbed by plant roots so that the available nutrients can increase plant growth.

\section{Methods}

The research applies a factorial completely randomized design (CRD) consisting of 2 treatment factors with three replications. The first factor was the Vermicompost (D) which consisted of 3 levels, namely: D0: Without Vermicompost (0\%) as Control; D1: Vermicompost of 14.67 tonnes ha ${ }^{-1}$ (100 g polybag $\left.{ }^{-1}\right)$; D2: Vermicompost of 29.33 tonnes ha ${ }^{-1)}\left(200 \mathrm{~g} \mathrm{polybag}^{-1}\right)$. The second factor is the application of NPK fertilizer as a comparison consisting of M0 (Control); M1: NPK 0.15 ton ha ${ }^{-1}$
(1 g polybag-1 $\mathrm{g}^{-1}$. From the two treatment levels above, there are 6 treatment combinations, each combination is repeated 3 times so that there are 18 experimental units.

Parameter observed were plant height, number of leaves, fresh root weight that carried out destructively at harvest, total fresh plant weight that measured at harvest. The result was analyzed with Analysis of variance (F-test) at 5\% and 1\% $\alpha$-level followed by Tukey test at $\alpha$ of $5 \%$ level.

\section{Results and Discussions}

\section{Plant height}

Green mustard plant height observations were carried out at $1 \mathrm{WAP}$ (week after planting) to 4 WAP. The results of the analysis of variance showed that there was no interaction between application of Vermicompost and NPK Fertilizer on Green Mustard plant growth, but the single NPK factor had a significant effect on the age of 3 and 4 WAP, while the single factor Vermicompost did not show a significant effect on the growth of green mustard plants. The average height of green mustard plant at of 1 to 4 WAP with NPK can be seen in Table 1.

Table 1. Average plant height of the effect of NPK fertilizer on green mustard plants

\begin{tabular}{cllrl}
\hline & & \multicolumn{3}{c}{ Age of plants } \\
Treatment & 1 WAP & 2 WAP & 3 WAP & 4 WAP \\
\hline M0 & $8.30 \mathrm{a}$ & $11.30 \mathrm{a}$ & $12.82 \mathrm{a}$ & $13.90 \mathrm{a}$ \\
M1 & $10.63 \mathrm{~b}$ & $17.76 \mathrm{~b}$ & $22.42 \mathrm{~b}$ & $24.24 \mathrm{~b}$ \\
\hline
\end{tabular}

Note: Numbers followed by the same letter in the same row or column are not significantly different according to the $5 \%$ HSD test.

Based on Table 1, it is known that at the age of 1 to $4 \mathrm{WAP}$ has a very significant effect on NPK (M) on the growth of Green mustard plants, which significantly affects M1 treatment (0.15 ton / ha). The administration of Vermicompost and NPK at specific doses did not significantly differ in Green mustard plants. This is because the nutrients in the peat soil as a planting medium have been fulfilled. There is no difference in the combination treatment of Vermicompost and NPK with a certain dose compared to the single factor NPK, presumably due to excess nutrients in the treatment of Vermicompost fertilizer with NPK. According to Setyamidjaya (1986), excessive fertilization no longer encourages growth to be more active but instead begins to suppress the rate of plant growth. Plants cannot use the application of Vermicompost to the growing media for growth, where Vermicompost is an organic fertilizer that plays a role in improving soil structure. Masnur (2001) states that Vermicompost plays a role in improving soil structure and neutralizing soil $\mathrm{pH}$. As a soil aggregation to improve the soil's physical, chemical, and biological properties, it can also form an amalgamation with micro-nutrients (Sanches, 1992). The treatment that showed the highest average height of Green mustard plants, namely the provision of Vermicompost $(100 \mathrm{~g})$ and NPK $(1 \mathrm{~g})$ fertilizers had a better average high yield compared to other treatment combinations, it 
is presumed that the Vermicompost fertilizer application of $100 \mathrm{~g} /$ polybags can improve the physical, biological, and chemical properties of the soil. The physical properties of the soil include soil structure, water storage, air exchange (aeration) and soil drainage. Number of Leaves Observation of the number of green mustard leaves was carried out at 1 WAP - 4 WAP. The results of the analysis of variance did not show any interaction between the application of Vermicompost and NPK fertilizers on the growth of green mustard plants. However, the single factor of NPK had a significant effect on the age of 3 and 4 WAP while the single factor of Vermicompost fertilizer did not significantly affect the growth of Green mustard plants. The results of the average number of green mustard leaves at the age of 1 - 4 WAP with the provision of Vermicompost and NPK fertilizers can be seen in Table 2 .

Table 2. Average number of leaves, the effect of NPK fertilizer on green mustard plants (WAP)

\begin{tabular}{ccccc}
\hline & & & Ages & \\
Treatment & $1 \mathrm{WAP}$ & $2 \mathrm{WAP}$ & $3 \mathrm{WAP}$ & $4 \mathrm{WAP}$ \\
\hline M0 & 7,00 & 8,67 & $1,00 \mathrm{a}$ & $11,44 \mathrm{a}$ \\
M1 & 8,11 & 12,56 & $18,80 \mathrm{~b}$ & $27,33 \mathrm{~b}$ \\
\hline
\end{tabular}

Note: Numbers followed by the same letter in the same row or column are not significantly different according to the 5\% HSD test.

In the graph of the average number of leaves, it can be seen that the single factor NPK on the parameter of the number of leaves with NPK $1 \mathrm{~g} /$ polybag M1 has better results than single factor D1 with Vermicompost fertilizer, this is due to the nitrogen element in the fertilizer. NPK can be used efficiently so that it can trigger the growth of leaf numbers. While the treatment factor with Vermicompost Fertilizer $100 \mathrm{~g} /$ polybag and NPK $1 \mathrm{~g} /$ polybag had the highest average number of leaves, namely at 4 WAP as many as 29.67 strands, this is more than other dosage treatments. This is presumably because the availability of nutrients in the soil has met the needs of plants for growth. Nyakpa et al (1988) stated that the process of leaf formation cannot be separated from the role of $\mathrm{N}$ and $\mathrm{P}$ nutrients found in the planting medium and available to plants. In the treatment of Vermicompost fertilizer $200 \mathrm{~g} /$ polybag and NPK $1 \mathrm{~g} /$ polybag, which were the highest doses, the number of leaves was 23.67 pieces lower than the treatment of Vermicompost fertilizer $100 \mathrm{~g} /$ polybag and NPK fertilizer $1 \mathrm{~g} /$ polybag. This is because the addition of excess nutrients will suppress the availability of other nutrients which causes an unbalanced condition in the soil. Total Plant Weight Observation of the total weight of green mustard plants was carried out at the time of harvesting. The analysis of variance did not show any interaction between the application of Vermicompost and NPK fertilizers on the growth of green mustard plants, but the single NPK factor had a significant effect on the total plant weight. while the single factor of Vermicompost Fertilizer showed no significant effect on the growth of Green mustard plants. The results of the average number of leaves of the Green mustard plant at the time of harvesting with Vermicompost and NPK fertilizers can be seen in Table 3 .

Table 3. Average Total Plant Weight

\begin{tabular}{cc}
\hline Treatment & Total Plant Weight (gr) \\
\hline M0 & $9.09 \mathrm{a}$ \\
M1 & $67.69 \mathrm{~b}$
\end{tabular}

Note: Numbers followed by the same letter in the same row or column are not significantly different according to the $5 \%$ HSD test.

Based on table 3, the average total weight of single-factor plants, application NPK fertilizer can be seen that the application of NPK M1 fertilizer has the highest average graph, reaching $67.69 \mathrm{~g}$, which is very different from the M0 treatment, which only reaches 9.09 g. Although not significantly different, the factors of application Vermicompost Fertilizer $100 \mathrm{~g} /$ polybag and NPK 
$1 \mathrm{~g} /$ polybag had the highest average graph $88.8 \mathrm{~g}$ compared to other treatments. In comparison, the lowest green mustard plant weight was in the control treatment D0M0. Diversity analysis showed that the NPK fertilizer dose treatment significantly affected Green mustard plants' average weight. This is because the water and nutrient content in the leaves is quite optimal, resulting in the highest plant weight. This is in line with the opinion of Lahadassy et., Al. (2007), to achieve optimal plant fresh weight, plants still need a lot of energy and nutrients so that the increase in the number and size of cells can be optimal and allow for an optimal increase in plant water content, most of the plant's fresh weight is caused by water content. Water plays a role in cell turgidity, so that the leaf cells will enlarge. Root
Weight Observation of root weight was carried out at the time of harvesting, where the measurement of the root weight itself was weighed using analytical scales and the root weight that was weighed, namely the weight of the fresh roots. The analysis of variance did not show any interaction between the application of Vermicompost and NPK fertilizers on the growth of green mustard plants, but the single NPK factor had a significant effect on root weight. while the single factor of Vermicompost Fertilizer showed no significant effect on the yield of Green mustard plant root weight. The average root weight of green mustard plants when harvested with NPK is shown in Table 4.

Table 4. Average Plant Root Weight

\begin{tabular}{cc}
\hline Treatment & Plant Root Weight (gr) \\
\hline M0 & $5.24 \mathrm{a}$ \\
M1 & $24.09 \mathrm{~b}$ \\
\hline
\end{tabular}

Note: Numbers followed by the same letter in the same row or column are not significantly different according to the $5 \%$ HSD test.

Based on table 4, it is known that at the time of harvesting, the root weight of Green mustard plants has a significant effect on the single factor application NPK $1 \mathrm{~g}$ / polybag (M1) while the single factor Vermicompost Fertilizer does not show a significant difference but the highest Vermicompost Fertilizer factor is in the administration with a dose of $100 \mathrm{~g}$. / polybag (D1) with a total of $21.67 \mathrm{~g}$. The combination factor between Vermicompost and NPK fertilizers did not significantly affect all combinations with different doses. The highest combination factor between Vermicompost and NPK was in the D1M1 treatment, which weighed $38.63 \mathrm{~g}$, and the lowest was D0M0 with an average total of $2.1 \mathrm{~g}$. In the application of both Vermicompost fertilizer, the single factor is still not able to increase the root weight of Green mustard plants where the single factor Vermicompost fertilizer at a dose of $100 \mathrm{~g} /$ polybag D1 is only able to produce a root weight of $4.7 \mathrm{~g}$, and Vermicompost fertilizer at a dose of 200 $\mathrm{g} /$ polybag can only produce $8.93 \mathrm{~g}$. The highest dose for the single factor Vermicompost fertilizer itself is still less when compared to the results of the single factor NPK $1 \mathrm{~g} /$ polybag M1 which has a root weight of $15.57 \mathrm{~g}$. It is suspected that the administration of $100 \mathrm{~g}$ and $200 \mathrm{~g} /$ polybag doses of Vermicompost fertilizer has not been able to improve soil structure and increase plant growth, such as gibberillin, cytokinins, and auxins. According to Mulat (2003), a large number of microbes and high activity can accelerate the process of mineralization or release of nutrients from worm droppings into available forms for plants. Provision of Vermicompost Fertilizer 200 $\mathrm{g}$ /polybag and NPK Fertilizer $1 \mathrm{~g} /$ polybag (D2M1) is a treatment with the highest dose but produces lower root weight when compared to Vermicompost fertilizer treatment $100 \mathrm{~g} /$ polybag and NPK $1 \mathrm{~g} /$ polybag (D1M1). This is because the application of fertilizers with excessive doses causes the balance of fertilizers in the soil to not occur, so that plants do not completely absorb nutrients and consequently can inhibit root development and plant growth.

\section{Conclussion}

The interaction of the application Vermicompost Fertilizer and NPK Fertilizer at certain doses did not significantly affect plant height, leaf number, root weight, and total plant weight on the growth and 
yield of Green mustard plants. Vermicompost dosage of $100 \mathrm{~g} /$ polybag and NPK $1 \mathrm{~g} /$ polybag gave the highest yield on the growth and yield of Green mustard plants. This can be seen from all parameters. Giving NPK $1 \mathrm{~g} /$ polybag had a very significant effect on the observation parameters of plant height, number of leaves, root weight, and total plant weight.

\section{References}

Ahmad D, Husna Y, dan Sri Y. 2015. Pengaruh Pemberian Pupuk Vermicompost dan NPK Terhadap Pertumbuhan dan Hasil Tanaman Jagung Manis. Fakultas pertanian. Universitas Riau. Riau

Arief, A. 1990. Hortikultura. Penerbit Andi Offset. Yogyakarta.

Balai Besar Litbang Sumber daya Lahan Pertanian. 2011. Peta Lahan Gambut Indonesia skala 1:250.000. Balai besar Penelitian dan Pengembangan Sumber daya Lahan Pertanian, Kementerian Pertanian. Bogor.

Direktorat Jenderal Hortikultura. 2015. Statistik Produksi Hortikultura Tahun 2014. Kementerian Pertanian. Jakarta.

Febrianti F, Wardati, dan Arnis E. 2016. Pengaruh Pupuk Vermicompost dan NPK Terhadap Pertumbuhan Bibit Tanaman Kakao. Fakultas pertanian. Universitas Riau. Riau

Hardjowigeno, S. 1986. Sumber daya fisik wilayah dan tata guna lahan: Histosol. Fakultas Pertanian Institut Pertanian Bogor. Hal. 8694.

Imran, M. 2005. Optimasi Pengomposan Sampah kebun Dengan Variasi Aerasi dan Penambahan Kotoran Sapi Sebagai Bioaktivator. Jurnal Ilmiah Teknik Lingkungan Vol. 4, No.1.

Iskandar, D. 2003. Pengaruh dosis pupuk N, P, dan $\mathrm{K}$ terhadap produksi tanaman jagung manis di lahan kering. Prosiding Seminar Untuk Negeri, vol $2: 15$.

Kartini, N. L. 1999. Pupuk Vermicompost (Kotoran Cacing) Sebagai Pupuk Organik dan Peranannya Bagi Tanah dan Tanaman. Topik Khusus. Program Pasca Sarjana, UNPAD. Bandung.
Komang M, Ni luh K, dan I wayan D. 2015. Pengaruh Dosis Pupuk Vermicompost Terhadap Hasil Tanaman Green mustard, sifat kimia dan Biologi pada Tanah Inceptisol Klungkung. Fakultas pertanian. Universitas Udayana. Bali

Kosasih, A. S. dan Heryati. 2006. Pengaruh medium sapih terhadap pertumbuhan bibit Shorea selanica $B$. Di persemaian. Jurnal Penelitian Hutan dan Koservasi Alam. Pusat Litbang Hutan dan Konservasi Alam. Bogor.

Krishnawati, D., 2003. Pengaruh pemberian pupuk Vermicompost terhadap pertumbuhan vegetatif tanaman kentang (Solanum tuberosum). KAPPA (2003) Vol. 4, No.1, 9-12.

Lahadassy J, Mulyati AM, Sanaba AH. (2007). Pengaruh Konsentrasi Pupuk Organik Padat Daun Gamal terhadap Tanaman Green mustard, Jurnal Agrisistem, Vol 3.

Lakitan, B., 1996. Fisiologi Pertumbuhan dan Perkembangan Tanaman. PT Raja Grafindo Persada. Jakarta

Lun. 2005. Pupuk Vermicompost Kurangi Pencemaran Lingkungan. Penebar Swadaya. Jakarta.

Margiyanto, E. 2008. Budidaya Tanaman Green mustard.http://zuldesains.wordpress.com. Diakses tanggal 27 November 2017

Masnur, 2001. Vermikompos (Kompos Cacing Tanah).Istalasi Penelitian dan Pengkajian Teknologi Pertanian (IPPTP) Mataram.

Mulat, T. 2003. Membuat dan Memanfaatkan Vermicompost Pupuk Organik Berkualitas. Agro Media Pustaka. Jakarta.

Novizan. 2007. Petunjuk Pemupukan Yang Efektif. Jakarta: AgroMedia Pustaka.

Nyakpa, M.Y., A. M. Lubis, M. A. Pulung, A. G. Amrah, A.Munawar, G. B. Hong, N.Hakim. 1988. Kesuburan Tanah. Universitas Lampung. Bandar Lampung.

Puspadi, N,K.1996. Pengaruh Varietas Dan Populasi Terhadap Pertumbuhan Dan Hasil Tanaman Green mustard (Brassica juncea 
(L).). Skripsi. Konsentrasi Ilmu Tanah dan Lingkungan Fakultas Pertanian Universitas Udayana.

Radjagukguk, B.2001.Perubahan sifat-sifat fisik dan kimia tanah gambjt akibat reklamasi lahan gambut untuk pertanian. Jurnal ilmu tanah dan Lingkungan Vol 2, No 1-15.

Rukmana, R. 2002. Bertanam Petsai dan Green mustard. Kanisius. Yogyakarta.

Sabiham S, Supardi G. dan Djokodudardjo S. 1989. Pupuk dan Pemupukan. Fakultas Pertanian, Institut Pertanian Bogor. Bogor.

Sanches, P.A. 1992. Properties and Management of Soil in theTropics. Diterjemahkan menjadi sifat dan pengelolaantanah tropik oleh J.T. Jayadinata. ITP Bandung. Hal.115-125.
Sarief, E.S. 1986. Kesuburan dan Pemupukan Tanah Pertanian. Pustaka Buana. Bandung.

Setyamidjaya, D. 1986. Pupuk dan Pemupukan. Simpleks. Jakarta.

Winarso, S. 2005. Kesuburan Tanah: Dasar Kesehatan dan Kualitas Tanah. Gava Media. Yogyakarta.

Winten, K.T.I. 2006. Pengaruh Dosis Pupuk Vermicompost Dan Nitrogen Terhadap Pertumbuhan Dan Hasil Selada (Lactuca sativa L) (tesis). Program Pascasarjana Universitas Udayana Denpasar.

Zahid, A. 1994. Manfaat Ekonomis Dan Ekologi Daur Ulang Limbah Kotoran Ternak Sapi Menjadi Vermicompost. Studi Kasus Di PT. Pola Nusa Duta, Ciamis. Fakultas Kedokteran Hewan, Institut Pertanian Bogor, pp. 6-14. 